\title{
Summary of the Papers Presented at the 2015 Conference of IIAS and Published in "Atlanti" 2015
}

\author{
ChARLES KECSKEMÉTI, P P.D. \\ former Secretary General of ICA \\ e-mail: k.kecskemeti@orange.fr
}

\section{Tome 1: Management, Appraisal and Long Term Preservation of E-records: Archi- val Response to the Challenge of Long Term Preservation}

\section{Inaugural session}

In her opening address (13), Giulia Barrera, President of the Assembly of the Members of IIAS, pointed out the importance of the role of the archival community in preserving the cultural heritage under threat in a dramatic international context. In spite of financial difficulties, the Italian Ministry of Cultural Heritage continued to support IIAS. Greetings were delivered by the representative of the General Consulate of Romania, Grazia Tatò, Director of the IIAS Autumn Archival School, Liliana Bagalà, Director of the State Archives of Trieste (17), Ludvik Toplak, President of Alma Mater Europea, European Centre Maribor (19) and the representatives of the National Archives of Slovenia, of the National Association of Slovenian Archivists and of the National Archives of Croatia. Jonathan Rhys-Lewis reported then on the activities of ICA's Expert Group on Archival Buildings and Environments (EGABE).

\section{Report}

Peter Pavel KLASINC, presented his report on the activities of the IIAS Executive Committee from November 2014 to October 2015 (25).

Contact was maintained with IIAS members in 27 countries. (31).

Charles KECSKEMETI presented then the Summary of the papers published in "Atlanti" 2014

\section{General introduction}

Peter Pavel KLASINC, From Classical Problems to Contemporary in Archives and in Archival Science (43).

With the constant development of information technologies, archival theory and practice are undergoing fast changes. Archivists should master, together with the traditional methods of preserving paper records, the systems of protecting electronic records. In view of this need, many countries decided to establish electronic archives both at central and regional levels.

\section{Management, Appraisal and Long Term Preservation of E-records: Archival Response to the Challenge of Long Term Preservation}

Miroslav NOVAK, Evaluation of Archival Material and Re-Use of Information in the Public Sector (53).

Re-use of public sector information preserved in archival material is governed in the European Union by the Directive 2013/37/EU of the European Parliament. Digitization constitutes an important instrument in facilitating the implementation of this Directive. The archival profession should devote more international effort to deal with this issue. 
Andrei RYBAKOU, Management, Appraisal and Preservation of Electronic Records: the Belarusian Experience (61).

The Belarusian legislation makes distinction between records in electronic form, which may be unsigned and electronic records certified by EDS (electronic digitized signature). The same requirements apply to the storage and the same principles are followed in the appraisal of traditional and electronic records. E-records are preserved up to 10 years. For long term preservation paper records are created.

Siniša DOMAZET, Archival Response to the Challenge of Long Term Preservation: Archives of Bosnia and Herzegovina in the Era of Digitization (71).

The Archives of Bosnia and Herzegovina are carrying out preservation projects in spite of the shortage of resources and the limited number of experienced staff. In 2006, the Government of Japan donated a microfilm laboratory. Digitization of records started in 2013; it is planned to make them accessible on the web. In order to facilitate research microfilms are scanned.

Alizata KOUDA, Management of Public Archives in Burkina Faso: Security and Perennial of Electronic Data (81).

The archival legislation of Burkina Faso prescribes the preservation of the e-records. In carrying out a study on the management of the e-archives produced by public bodies, 113 persons were consulted. The study covers the creation, the security and the evidential value of the e-records, the training of agents, and the archiving policy. Successful implementation of this policy requires support by decision-makers and cooperation between archivists and information specialists.

Omer ZULIĆ, Specifics of Evaluating Archival Material in Bosnia and Herzegovina During the Transitional Period (95).

The development of adequate principles and criteria for the appraisal of the archival holdings produced during and after the war is a high priority task in Bosnia and Herzegovina. The paper reports on the experience of the Archives of Tuzla Canton in appraising special material such as the TV records on the war or the archives of humanitarian NGOs. In order to formulate appropriate solutions, it was necessary to keep up with the European evolution.

Robert NAHUET, Management, Appraisal \& Preservation of Government Records: Some Aspects of the Canadian Case (103).

Canadian archivists believed that the government records were properly managed. The record system of the federal agencies is based on the Macro-Appraisal by LAC (Library and Archives of Canada). The 2014 report of the Auditor General pointed out weaknesses and failures in LAC activities, such as the backlog in transfers from the agencies and in the updating of disposal authorizations. LAC commissioned a task force to offset the backlog and to develop a strategy for the transfer of e-records.

Ivana POSEDI - Irena MILOBARA, The Legal Framework of Application and Protection of E-Records in the Republic of Croatia (111).

While the Croatian archives are bound to accession and preserve the e-records produced by government agencies, the legal situation is unclear, because the existing texts cover only part of the issues. A new archival law should regulate the protection, preservation and use of e-records and provide for sanctions in case of unauthorized destructions.

*Triantafillia KOURTOUMI, Web 2.0 in the Archival Domain: Why and How in the Knowledge Economy? (121).

In the knowledge economy, Web 2.0 applications used by archives are on the increase. The paper describes the impacts and benefits resulting from that innovation and the challenges involved by the technological, cultural and pedagogic change. It examines issues in content, metadata quality, and knowledge dissemination policy that are important from the perspective of archival methodology.

*. The author did not take the floor at the session. 
Živana HEĐBELI - Nikola MOKROVIĆ, Managing a Photograph Collection: ARKzin photo archive Case Study (131).

The magazine ARKzin, published from 1991 to 1998 within the anti-war campaign, contain a collection of 1500 photographs on atrocities, protests and social events as well as portraits of people interviewed. The holding is preserved in the Documenta centre. The identification of the objects represented and of the authors of the photographs, currently underway, will permit to arrange the collection.

Lajos KÖRMENDY, Information Society, E-Records and the New Archival Science (141). The production of dematerialized e-records imposed to rethink archival science. Long-term preservation is hampered by the constant and rapid change of hardware and software. In order to preserve the integrity and authenticity of e-records, archives choose either the migration strategy involving inevitable losses or the emulation strategy implying the difficulty of the legal protection of the software to be used. In spite of the explosion of quantity and the complex structure of e-records, archivists should keep the classical method of organising and describing the fonds.

Fikrie BERISHA, Digital Archives Management and Permanent Storage of Documents (153).

The management and storage of both digitized paper records and e-records require appropriate standards and procedures. The State Archives of Kosovo introduced the texts that ensure the legal protection and acquired the technology needed for the processing and use of the digital archives. It is planned to install a server for storage, a server for access and an isolated server for classified documents. New IT solutions will be needed to secure long-term (more than 15 years) preservation.

Snežana PEJOVIĆ, Among Technological Reality, Legislation and Practice: Montenegrin Archivists Facing the Challenge of Long-Term Preservation of E-Records (163).

Montenegro entered the age of the production of e-records. The Electronic Documents Management System, introduced by the Government in 2009, is implemented in all departments under the authority of the Ministry for Information Society and Telecommunication. The Sate Archives entered the field as late as 2013 and play a limited role because the staff lacks professional knowledge and is interested only in the custody of traditional archives.

Ismail ISMAILI - Refike SULÇEVSI, The Era of Electronic Documents and the Challenges Facing Their Management (175).

The preservation of and easy access to textual and iconographic documents require the combination of microfilming and digitization. The Kosovo State Archives, engaged in this work, face the double difficulty of the scarcity of financial means and of qualified manpower.

Bogdan Florin POPOVICI, Electronic Records Management in Romania: More Electronic-, Less Records-Management (183).

Development of IT started in Romania in the 1960s, but most of the e-records produced before 2000 are lost. A coherent IT program was launched in the pubic administration in 2001. A series of texts govern the production of e-records in both the public and private sectors without any reference to the archives. The National Archives are not involved in electronic records management. The extension of the national IT system to public archives is hindered by the lack of qualified and motivated staff.

Alessandro ALFIER, Digital Archives Preservation: a "Culture Broth" for a New Archival Para$\operatorname{digm}(193)$.

Long-term preservation of digital records is the main challenge that the archival institutions are faced with. The paper analyses the action carried out by the Polo archivistico regionale dell'Emilia-Romagna (ParER) offering preservation services to all public agencies operating in the region. The experience led to the conclusion that the archival paradigm should be revised e.g. with respect to the life cycle of records, the concept and nature of description and the communication with users. 
Mikhail LARIN, Scientific and Methodical Solutions of Long-Term Storage of Electronic Records in the Russian Federation (211).

VNIIDAD (All-Russian Scientific and Research Institute for Archives and Records Management) participated, during the last years, in the development of a unified methodology for long-term storage of e-records and prepared a dictionary of terminology. The Rules of storage, acquisition, control and use of records (including e-records) has been submitted for registration to the Ministry of Justice. E-records to be preserved are converted in PDF/A-1 format. Research is conducted in cooperation with scientists for completing and improving the regulations.

Aida ŠKORO BABIĆ, Management, Appraisal and Long Term Preservation of E-records: Role of Archivists and IT Professionals (217).

Both IT professionals and archivists are involved in securing the digital preservation of the cultural heritage. It belongs to the IT specialists to ensure the proper management of e-records, safe environment, safe format and the defence against hackers. Archivists are in charge of the appraisal (both rules and practice), they are accountable of the preservation and accessibility of the e-records, in accordance with archival standards and principles. IT professionals who deal with e-archives should have a good understanding of the basic elements of archival science.

\section{Olivera PORUBOVIĆ-VIDOVIĆ, Digital Master Document: New Original (225).}

Digital master copies, produced for protecting the original documents, have to be submitted to thorough quality control so as to avoid new scanning. Should be controlled, possibly through sampling, sharpness, completeness, resolution, file format, file name and compression.

Anja PAULIČ, European Archival Records and Knowledge Preservation (E-ARK) Project. Goals and Achievements: an Overview (237).

The aim of the 3-year project (2014-2017) is to create a pan European methodology for keeping e-records authentic and reusable in the long term. The paper presents the goals of the eight work packages: Project Management, Use cases, Transfer of records to Archives, Preservation, Access, Archival storage, Assessment and Dissemination to potential users. The implementation of the project is progressing according to schedule.

Maria GUERCIO, Certification and Trusted Digital Repositories: the Role of Standards and Policies (245).

Although no European project has been devoted to the memory institutions, intensive international effort has been conducted during the past 15 years for formulating principles and requirements to be observed for the preservation of digital records. The paper analyses the existing security and data protection standards and the difficulties of their application.

Antonio MONTEDURO, The ANAI Code of Ethics (257).

The Italian text and the English version of the updated Code of Ethics of the Italian National Association of Archivists, which came into force on January $1^{\text {st }} 2015$.

*Susanne FRÖHLICH - Elisabeth SCHÖGGL-ERNST, Digital Long-Term-Preservation in Austria (265).

The Austrian State Archives already have established an electronic long-term archive for the permanent storage of digital data, called "Digital Archive Austria", based on the Open Archival Information System (OAIS). For reasons of cost efficiency the Austrian Federal Chancellery has purchased a general license enabling all Austrian provinces, cities, communities and other public authorities to use this archive solution without having to pay license fees all over again.

IIAS Descriptors (284) in English, Italian, Slovenian, German, French and Spanish from 2.1 Climate to 3.6 Storage containers. 


\section{Tome 2: Archival Buildings in Terms of Responding to the Emergencies}

Grazia TATÒ, Keep Calm: Archives Between Disasters and Prevention (11).

The Italian archives were hit by a series of disasters in the last decades. The Guidelines for Risk Prevention and Emergency Response in the Archives prepared by Italian Ministry for Cultural Goods and Assets and Tourism in 2014, describe the preventive tools for reducing the damages and the emergency measures to be taken in case of earthquake, landslide, flood or fire.

Azem KOŽAR, Location Characteristics of Archival Buildings in Bosnia and Herzegovina

The paper gives the characteristics of 30 facilities of the 11 archival institutions of Bosnia Herzegovina and of their location with respect to emergencies (war, flood etc.). Since 1990, with the construction of new buildings in Travnik and Brčko, the archival space grew from 11000 to $15000 \mathrm{~m}^{2}$, which meets half of the space needed.

Cristina BIANCHI, Emergency planning in Switzerland (25).

In neutral Switzerland, a safe country, the Protection of Cultural Goods service (PCB), prepares emergency plans, including lists of goods to evacuate, and intervenes in case of disaster. In 2015, a paragraph was added to the federal law on the protection of cultural property during armed conflicts, which offers temporary storage - "safe haven" - to threatened foreign works of art, libraries and archives.

Izet ŠABOTIĆ, Archival Building: the Condition of Safeguarding Archival Material in Extraordinary Circumstances (35).

Because of the inadequacy of archive and registry facilities, riots and flood hit severely both historical and current records in Bosnia Herzegovina. Thus the National Archives, located on the ground floor of the Presidency, was destroyed by fire. For avoiding similar damages, the accommodation of the archival material should receive more attention.

Jasna POŽGAN, Buildings in the Northern Croatia: Conditions and Possibilities (45).

With the exception of the purpose-built State Archives of Karlovac, all Croatian public archives are stored in adapted buildings. The paper surveys the history of the accommodation of the Varaždin, Bjelovar and Medimurje regional archives, founded respectively in 1951, 1961 and 2007. Only the latter institution is located in one building, in the two other regions the archives are operating in several seats. The public opinion should be sensitized to support expenditures for archive facilities by regional and local authorities.

Marie RYANTOVÁ, Archive Buildings in the Czech Republic After 1990: the "Czech Archival Wonder" and the Present Situation (53).

Before 1989, with the exception of the Archives of the Land of Bohemia, the Hodonin and the Most regional archives, all public archival institutions were located in unsuitable adapted buildings. An intensive construction program was launched in 1991. From 1991 to 2003, 21 new archival buildings were constructed and 29 buildings adapted and enlarged. The Central State Archives, the Prague Regional Archives and the Prague City Archives have their new buildings in Chodovec. The new seat of the Moravian Provincial Archives in Brno, the most modern archive building in the Czech Republic was inaugurated in 2007. The current situation is satisfactory, but new demands are constantly arising.

Christian KRUSE, Preparing for an Emergency: Building and Organisational Measures (61).

The first part of the article presents the architectural solutions chosen in Bavaria to equip the archives for facing emergency situations (fire and flood). The second part gives detailed information on the emergency associations of archives, possibly together with libraries and museums, created in towns and regions throughout Germany. The associations prepare emergency plans and proceed to emergency exercises. In Bavaria, an association has been created in Augsburg and the organisation is underway in Munich. 

tion (71).

T. Csaba REISZ, The History of the National Archive Hungary Central Building's Construc-

The article describes the history of the construction of the building of the National Archives founded in 1874. Because of the lack of experience in Hungary, study tours were completed in Western Europe in 1874, 1899 and 1905. After decades of hesitation, the decision to construct the building was taken in 1911 and the construction carried out between 1913 and 1918. The National Archives are operating in the building since 1923.

Habibe QOVANAJ - Shpresa MEKAJ, Emergency Planning for Records and Archives Service

Every year, large quantities of archival documents are destroyed in the world by natural or man made disasters. During the 1998-1999 war, historical and current records suffered heavy losses in Kosovo; the Municipal Archives of Decan was burnt. The emergency plan, to be prepared for each archival institution, comprises five segments: risk assessment - preventive measures - preparedness measures - rescue during disaster - recovery. In case of war, archives are protected under the 1954 Convention of The Hague.

Svetlana USPRCOVA, Archival Buildings in General and the Case with the Archival Buildings of the State Archives of the Republic of Macedonia (89). The paper recapitulates the basic safety and space planning requirements to be observed when constructing new or adapting old buildings for archival services. From January 2014, the State Archives of Macedonia is relocated in a new building shared with the Archaeological Museum and the Constitutional Court. The old repository, built in 1951, is maintained; future acquisitions will be stored in the new building.

Abdulmohsin Said AL HINAI, Building of the National Records and Archives Authority (NRAA) in the Sultanate of Oman: the Establishment, Designing, and Magnificence Construction (97).

The new building of the NRAA is located in the Oman Cultural Complex, which includes also the National Theatre and the National Library. The site is away from waterways and pollution sources, and permits easy contact with the government agencies. The 9-floor building contains 16 stack areas, offices, workshops, meeting room, training hall, laboratory, reading room and library. The paper gives the technical data on walls, roof, windows, floors, loading and shelves. The Korean BIOMASTER device is used for sterilization. An emergency plan has been prepared in linkage with the Civil Defence Department.

Svetlana PEROVIĆ IVOVIĆ - Irena IVOVIĆ, Archival Building Design Challenge: Architects, Archivists and Conservators have the Same Task in Order to Ensure Adequate Protection of Archives (111).

Cooperation is needed between the archivist and the architect to secure functionality and safety for the archive building. On the examples of the buildings of the Archives of Yugoslavia (completed in 1933), the Archives of Serbia (1928) and the Historical Archives of Belgrade (1972), the paper analyses the requirements for the choice of the location, space apportionment, storage design and disaster prevention.

Jelka MELIK - Mateja JERAJ, Archival Law and Regulation of Perservation of Current and Archival Records (121).

The authors discuss legal texts that contain provisions relating to the preservation of archives in Slovenia. The most important is the Act on the Protection of Documents and Archives and Archival Institutions, which came into force in 2006 and was partially revised in 2014. Archival records are also protected by the Penal Code; two articles provide a penalty of several years in prison for damage and destruction of archival records. The Regulation on the Protection of Documents and Archives is only partially implemented. Unfortunately, only archives and archivists are aware of the importance of the task of preservation, there is no-wider understanding. Despite their deficiency and inaccuracy, it would be a great success if the existing legal provisions on the maintenance of archives and records were taken into account. 
Mojca KOSI, Disabled Persons in Slovenian Archives Reading Rooms: the Problem of Accessibility (129).

The Act of November 24, 2010 forbids all kinds of discrimination afflicting disabled persons. Thus, the law guarantees their access to the cultural heritage. Archive buildings should be arranged and equipped for permitting the use of wheelchairs. The Historical Archives of Ptuj was adapted in 20102011 for receiving disabled persons.

Jovan P. POPOVIĆ, Unlawfulness in the archives management in ordinary and extraordinary circumstances (opposition of archival commandments and the consequences deriving from it) (135).

Experience shows that natural cataclysms (earthquakes, tsunami, flood etc.) cannot be foreseen nor prevented. As to social events, prevention by men is possible and protective measures provided for by legislation can and have to be applied. Unlawfulness, i.e. opposition to prescribed rules, must be sanctioned. The paper includes definitions of rights and regulations considered essential for the protection of archives.

Tim HARRIS, Strategic Positioning of Archives in Disaster Recovery Procedures (149).

The London Metropolitan Archives (LMA), the largest local archive in the UK, with over 100 $\mathrm{km}$ of shelving, has established itself a centre of excellence for emergency planning and disaster recovery. Discussions with Information Technology support and partnership with other related organisations enabled the vision of a disaster recovery centre for the City of London to be located in the LMA building. Extracts from LMA Emergency Planning and Recovery Manual are attached in Appendix.

Josef HANUS - Emília HANUSOVÁ, Archival Buildings in Terms of Responding to the Emergencies (155).

Archives, libraries and museums must have facilities appropriate for long term storage of the cultural heritage, conceived to respond to potential emergencies and threats. The paper quotes the danger of terrorist attacks and that of microbiological contamination through air conditioning systems. Cooperation of the custodians with architects, engineers and other experts is essential to secure protection of the buildings from such threats.

\section{Miscellany}

*Dušan JOVANOVIČ - Patricija JANKOVIČ - Borut BRATINA, Legal Process Outsourcing as Challenge for Lawyers and Archival Institutions in EU (163).

Most archival institutions are not in a position to finance the permanent employment of lawyers. Therefore, for important services law firms are to be hired. In the recent past, the legal profession experienced a shift towards the new model of outsourcing the work of attorneys to external vendors located domestically or abroad. Legal outsourcing, both onshore and offshore, is transforming law practice, as law firms and corporate legal departments seek to minimize costs, increase flexibility and expand their in-house capabilities.

Zdenka SEMLIČ RAJH, Archives and Emergency Planning: the Case of the Republic of Slovenia.

The paper announced in the program and presented at the session, is not included in Atlanti 2015.

IIAS Descriptors (178) in English, Italian, Slovenian, German, French and Spanish from 2.1 Climate to 3.6 Storage containers.

Guidelines for authors for the publication ATLANTI (181). 